\title{
Distribusi Muatan Padatan Tersuspensi (MPT) di Padang Lamun di Perairan Teluk Awur dan Pantai Prawean Jepara
}

\author{
Ita Riniatsih \\ Jurusan IImu Kelautan, Fakultas Perikanan dan Ilmu Kelautan, Universitas Diponegoro \\ JI. Prof. Soedarto, SH. Kampus UNDIP Tembalang, Semarang 50275 \\ Email : iriniatsih@yahoo.com
}

\begin{abstract}
Abstrak
Muatan padatan tersuspensi merupakan partikel bahan organik maupun anorganik yang melayang di kolom air. Salah satu fungsi fisik ekosistem padang lamun adalah untuk meredam arus dan gelombang, sehingga kondisi perairan di lingkungan padang lamun menjadi lebih tenang, Kondisi ini akan mempengaruhi sebaran muatan padatan tersuspensi di kokasi tersebut. Penelitian ini dilaksanakan pada bulan Agustus 2013 di padang lamun perairan Teluk Awur dan pantai Prawean Bandengan Jepara. Penentuan lokasi pengamatan penelitian dengan metoda deskriptif ini ditentukan secara purposive sampling methode. Hasil penelitian menunjukkan sebaran MPT tertinggi di Teluk Awur sebesar $0.056 \mathrm{mg} / \mathrm{liter}$ terdapat pada Substasiun A12, sedangkan untuk perairan pantai Prawean Bandengan sebesar 0,057 mg/l di Substasiun B11.
\end{abstract}

Kata kunci : Muatan Padatan Tersuspensi, Lamun, Distribusi

\section{PENDAHULUAN}

Ekosistem padang lamun merupakan salah satu ekosistem laut dangkal yang mempunyai peranan yang penting dalam kehidupan biota laut. Ekosistem padang lamun secara fisik,mempunyai fungsi sebagai perangkap sedimen yang berasal dari pantai. Vegetasi lamun yang lebat dapat meredam gerakan air yang disebabkan oleh arus dan gelombang, sehingga menyebabkan perairan di sekitarnya menjadi lebih tenang. Ekosisten padang lamun juga berfungsi sebagai pencegah erosi dan perangkap sedimen (Hutomo dan Azkab, 1987).

Sedimen yang berada di perairan pantai biasanya bersumber dari sedimen yang terbawa arus sungai ke laut maupun oleh longshore sediment transport (Triatmodjo, 1999). Sedimen yang terkikis di pantai atau yang terbawa oleh arus sungai dapat terangkut dan disebarkan oleh arus dan gelombang di laut. Bahan organik merupakan salah satu bagian penyusun sedimen atau substrat dasar perairan, Bahan organik tersebut merupakan timbunan sisa-sisa organisme perairan yang telah mati (Buckman dan Brady, 1982).
Sumber penting bahan organik sebagian besar berasal dari masukan dari daratan melalui aliran sungai. Hal ini menyebabkan di daerah pesisir yang berdekatan dengan muara sungai, biasanya terdapat kandungan bahan organik yang relative tinggi (Nybaken . 1988).

Bahan organik merupakan sumber nutrient yang penting, yang sangat dibutuhkan oleh organisme laut. Melalui proses dekomposisi oleh organisme pengurai, bahan organik di perairan akan dirombak untuk menjadi bahan anorganik sebagai nutrien penting di perairan. Selanjutnya nutrient tersebut akan dipergunakan dalam proses produksi oleh produsen perairan dan sangat menentukan produktivitas primer di perairan tersebut. Suplai bahan organik selain dari daratan juga merupakan hasil metabolisme organisme laut. Proses produksi fitoplankton, rumput laut atau organisme laut lainnya merupakan sumber bahan organik utama di perairan (Hutomo dan Azkab, 1987 ; Fortes, 1990).

Ekosistem padang lamun dengan vegetasi lamun dengan rimpang yang tumbuh menjalar dan saling terkait di 
bawah substrat dasar dapat berfungsi sebagai perangkap sedimen dan penstabil substrat dasar sehingga dapat mengurangi abrasi karena arus (Dawes, 1981). Selanjutnya Hutomo dan Azkab (1987) menjelaskan bahwa rimpang dan akar lamun dapat menangkap dan menggabungkan sedimen, dan dapat meningkatkan stabilitas permukaan substrat dasar di bawah lamun, sehingga perairan menjadi lebih jernih.

Kondisi kerapatan lamun di padang lamun perairan Teluk Awur dan pantai Prawean Bandengan, Jepara, dapat dikatakan masih relative baik (Riniatsih et al, 2007). Kerapatan lamun yang berbeda diduga akan berpengaruh terhadap sebaran bahan organik muatan padatan tersuspensi di perairan. Untuk itu penelitian ini penting dilakukan untuk melihat sebaran bahan organik sebagai muatan padatan tersuspensi diperairan sekitar padang lamun di Teluk Awur dan pantai Prawean Bandengan Jepara.

\section{MATERI DAN METODE}

Penelitian ini menggunakan metoda deskriptif dengan penentuan titik sampling dilakukan dengan metoda purposive sampling method berdasarkan pertimbangan perbedaan kerapatan vegetasi lamun di kedua lokasi pengamatan. Masing-masing stasiun pengamatan dibagi menjadi tiga substasiun dengan ulangan 3 kali untuk pengambilan sampelnya. Pengambilan atau pengukuran sampel MPT pada setiap stasiun dilakukan dengan metoda stratified random sampling (Sidjabat, 1992). Pada penelitian ini sampel muatan padatan tersuspensi (MPT) diukur pada bagian permukaan air, bagian tengah/kolom air dan bagian dasar perairan. Sampel air laut diambil menggunakan botol langsung, karena perairan tidak terlalu dalam.

Bersamaan dengan pengambilan sampel MPT dilakukan juga pengukuran parameter kondisi perairan secara in situ. Parameter kondisi perairan tersebut meliputi suhu, salinitas, kedalaman perairan, kecepatan arus, $\mathrm{pH}$ dan kecerahan.
Data tentang kerapatan vegetasi lamun diambil pada awal penelitian dengan merthode transek garis tegak lurus pantai (English et al, 1997). Pengamatan dilakukan sebanyak tiga kali ulangan tempat di setiap sub stasiun.

Analisa muatan padatan tersuspensi dilakukan menurut metoda yang digunakan oleh Alerts dan Santika (1984), dengan perhitungan sebagai berikut:

$$
\text { MPT }=\frac{(a-b) \times 100}{c}
$$

Dimana:

$$
\begin{array}{ll}
\mathrm{a} \quad \text { = } & \text { berat residu dan kertas saring }(\mathrm{mg}) \\
& \text { sesudah pemanasan } \\
\mathrm{b} & =\text { berat kering kertas saring }(\mathrm{mg}) \\
\mathrm{C} & =\text { volume sample air }(\mathrm{ml}) \\
\text { MPT }= & \text { muatan Padatan tersuspensi (mg/lt) }
\end{array}
$$

Adapun prosedur analisa adalah sebagai berikut (Utaminingsih et al, 1994):

1. Kertas saring dipanaskan dalam oven dengan suhu $105^{\circ} \mathrm{C}$ selama 1 jam. Kemudian didinginkan dalam desikator selama 15 menit dan ditimbang. Pemanasan dilakukan berulang hingga diperoleh berat konstan atau kehilangan berat sesudah pemanasan ulang kurang dari $0.5 \mathrm{mg}$.

2. Sampel dikocok dan diambil sebanyak $100 \mathrm{ml}$ dimasukkan ke dalam alat penyaring dengan kertas saring

3. Kertas saring dimasukkan ke dalam oven dengan suhu $105^{\circ} \mathrm{C}$ selama 1 jam. Setelah pemanasan dilakukan pendinginan dalam desikator kemudian ditimbang.

$$
\operatorname{TSS}(\mathrm{mg} / \mathrm{l})=\frac{(\mathrm{a}-\mathrm{b}) \times 100}{\mathrm{c}}
$$

dimana:

$$
\begin{aligned}
a & =\text { berat residu dan kertas saring }(\mathrm{mg}) \\
& \text { sesudah pemanasan } \\
\mathrm{b} & =\text { berat kering kertas saring (mg) } \\
\mathrm{c} & =\text { volume sample air (ml) } \\
\mathrm{TSS} \quad= & \text { Muatan Padatan Tersuspensi (mg/lt) }
\end{aligned}
$$

Adapun untuk melihat hubungan antara sebaran muatan padatan tersuspensi di perairan dengan kondisi kerapatan lamun dianalisis dengan melihat korelasi regresi. 


\section{HASIL DAN PEMBAHASAN}

Data yang diperoleh selama penilitian menunjukkan bahwa terdapat variasi sebaran muatan padatan tersuspensi di kedua lokasi penelitin. Hasil penelitian menunjukkan sebaran muatan padatan tersuspensi tertinggi di Teluk Awur sebesar $0.056 \mathrm{mg} /$ liter terdapat pada Substasiun A12, sedangkan untuk perairan pantai Prawean Bandengan sebesar 0,057 mg/l di Substasiun B11. Hasil pengukuran muatan padatan tersuspensi di ekosistem padang lamun perairan Teluk Awur dan pantai Prawean Bandengan Jepara disajikan pada Tabel 1 dan Tabel 2.

Data tentang kondisi kerapatan lamun selama penelitian di ekosistem padang lamun perairan Teluk Awur dan pantai Prawean Bandengan disajikan pada Tabel 3. Jenis lamun yang ditemukan di padang lamun perairan Teluk Awur meliputi Enhalus acoroides, Thalassia hemprichii, Syringodium isoetifolium, Cymodecea serrulata dan Haludule pinifolia. Sedangkan jenis-jenis lamun yang ditemukan di padang lamun pantai Prawean Bandengan meliputi Enhalus acoroides, Thalassia hemprichii, Syringodium isoetifolium, Cymodecea serrulata, Haludule uninervis dan Halophila ovalis.
Kerapatan lamun merupakan gambaran jumlah tunas atau tegakan persatuan luas pengamatan (individu $/ \mathrm{m}^{2}$ ). Seperti yang dijelaskan oleh Dawes (1981) bahwa salah satu fungsi ekologis secara fisik bagi ekosistem padang lamun adalah dapat mengikat sedimen yang ada di perairan dan proses pengikatan ini sangat tergantung dari tipe morfologi daun serta jumlah tegakan dari individu lamun.

Kerapatan total tertinggi di perairan Teluk Awur adalah pada substasiun A.3.3 dengan kerapatan total sebesar 134.8 ind $/ \mathrm{m}^{2}$. Sedangkan kerapatan total lamun tertinggi di perairan pantai Prawean Bandengan adalah pada substasiun B.2.3 dengan kerapatan total sebesar 116.5 ind $/ \mathrm{m}^{2}$. Kerapatan total lamun di perairan Teluk Awur lebih tinggi apabila dibandingkan dengan kerapatan total lamun di pantai Prawean bandengan Jepara. Hal ini diduga karena kondisi perairan di Teluk Awur lebih stabil dan sedikit ada gangguan, apabila dibandigkan dengan perairan padang lamun di pantai Prawean Bandengan yang merupakan jalur pelayaran untuk pendaratan ikan hasil tangkapan bagan yang banyak terdapat di perairan Bandengan. Secara lengkap data tentang kerapatan total lamun di kedua lokasi penelitian disajikan pada Tabel 3 berikut ini.

Tabel 1. Hasil pengukuran muatan padatan tersuspensi di Perairan Teluk Awur (mg/l)

\begin{tabular}{cccccccccc}
\hline \multirow{2}{*}{$\begin{array}{c}\text { Rata-rata } \\
\text { Sampling }\end{array}$} & A11 & A12 & A13 & A21 & A22 & A23 & A31 & A32 & A33 \\
\hline Atas & 0.034 & 0.055 & 0.054 & 0.034 & 0.044 & 0.033 & 0.052 & 0.031 & 0.034 \\
Tengah & 0.036 & 0.057 & 0.059 & 0.038 & 0.041 & 0.032 & 0.057 & 0.036 & 0.031 \\
Dasar & 0.041 & 0.057 & 0.056 & 0.028 & 0.038 & 0.035 & 0.056 & 0.041 & 0.027 \\
\hline
\end{tabular}

Tabel 2. Hasil pengukuran muatan padatan tersuspensi di perairan pantai Prawean Bandengan Jepara (mg/l)

\begin{tabular}{cccccccccc}
\hline Rata-rata & \multicolumn{8}{c}{ Sub Stasiun } \\
\cline { 2 - 11 } Sampling & B11 & B12 & B13 & B21 & B22 & B23 & B31 & B32 & B33 \\
\hline Atas & 0.055 & 0.039 & 0.064 & 0.031 & 0.046 & 0.034 & 0.032 & 0.041 & 0.034 \\
Tengah & 0.059 & 0.033 & 0.059 & 0.034 & 0.044 & 0.033 & 0.035 & 0.056 & 0.031 \\
Dasar & 0.057 & 0.034 & 0.064 & 0.028 & 0.037 & 0.039 & 0.032 & 0.053 & 0.033 \\
\hline
\end{tabular}


Tabel 3. Rata-rata Kerapatan Total Lamun di perairan Teluk Awur dan pantai Prawean Bandengan Jepara (ind $/ \mathrm{m}^{2}$ )

\begin{tabular}{cccccccccc}
\hline \multirow{2}{*}{ Substasiun } & \multicolumn{10}{c}{ Stasiun } \\
\cline { 2 - 11 } & \multicolumn{1}{c}{1} & \multicolumn{1}{c}{2} & \multicolumn{1}{c}{3} & \\
\hline Ulangan & 1 & 2 & 3 & 1 & 2 & 3 & 1 & 2 & 3 \\
\hline TelukAwur & 69,1 & 34,2 & 29,1 & 228,6 & 90,8 & 107,4 & 29,7 & 84,7 & 134,8 \\
Bandengan & 33,8 & 48,3 & 18,3 & 77,1 & 42,3 & 116,5 & 114,3 & 49,1 & 47,7 \\
\hline
\end{tabular}

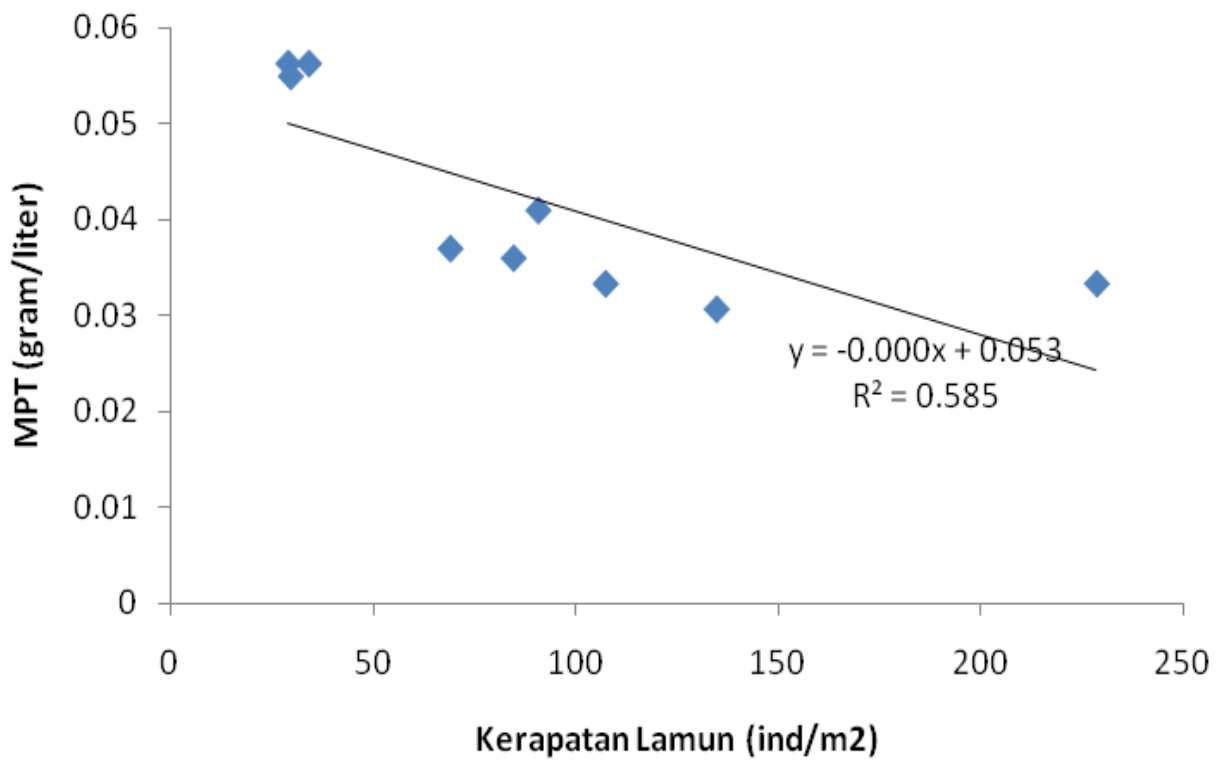

Gambar 1. Hubungan Korelasi antara distribusi sedimen muatan padatan tersuspensi dengan kondisi kerapatan lamun di ekosistem padang lamun perairan Teluk Awur Jepara

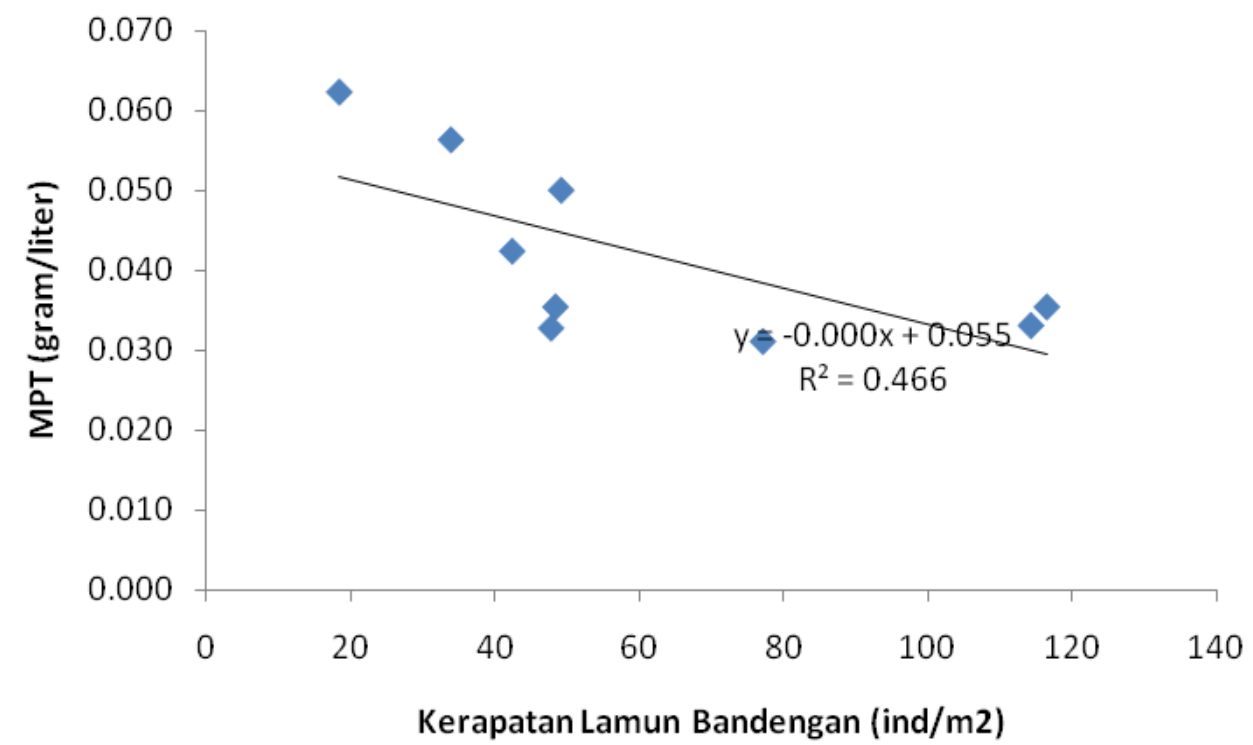

Gambar 2. Hubungan Korelasi antara distribusi muatan padatan tersuspensi dengan kondisi kerapatan lamun di ekosistem padang lamun perairan pantai Prawean Bandengan Jepara. 
Hasil analisis korelasi menunjukkan bahwa semakin tinggi nilai kerapatan lamun, maka akan semakin rendah sebaran sedimen muatan padatan tersuspensi yang terdapat di perairan. Secara umum kandungan muatan padatan tersuspensi yang terukur selama penelitian masih berada dalam kisaran yang layak menurut baku mutu air laut yang diperbolehkan, yaitu sebesar < 80 $\mathrm{mg} /$ liter atau 0,080 gram/liter. Data hasil penelitian menunjukkan bahwa kandungan sebaran muatan padatan tersuspensi di perairan Teluk awur cenderung lebih tinggi apabila dibandingkan muatan padatan tersuspensi yang terukur di pantai Prawean Bandengan. Hal ini diduga karena terkait dengan perbedaan kondisi kerapatan lamun di kedua lokasi tersebut.

Semakin tinggi kerapatan lamun, semakin banyak bahan organik yang terikat di dasar perairan. Kondisi padang lamun yang rapat dapat menenangkan arus dan gelombang, sehingga muatan padatan tersuspensi yang melayang di kolom air cenderung lebih mudah mengendap di dasar perairan. hal ini sesuai dengan pendapat Hutomo dan Azkab (1987) dan Kiswara dan Winardi (1999) yang menyatakan bahwa salah satu fungsi ekosistem padang lamun adalah untuk menyaring sedimen terlarut dalam air dan menstabilkan sedimen substrat dasar Perairan.

Dasar perairan dengan tutupan vegetasi lamun yang tinggi dapat menenangkan perairan juga memperkecil terjadinya pengadukan sedimen substrat dasar oleh arus. Hal ini diduga sebagai salah satu faktor yang mempengaruhi muatan padatan tersuspensi yang terukur di perairan padang lamun Teluk Awur cenderung lebih kecil bila dibandingkan muatan padatan tersuspensi yang terukur di pantai Prawean bandengan Jepara.

Hasil analisa regresi menunjukkan bahwa antara kerapatan total lamun dengan kandungan muatan padatan tersuspensi yang terukur mempunyai hubungan korelasi negative dengan persamaan $Y=-0,000 X+0,053$ dengan $R^{2}$ $=0,585$ di perairan Teluk Awur dan $Y=$ -
$0,000 X+0,055$ dengan $R^{2}=0,466$. Hal ini menunjukkan bahwa semakin tinggi nilai kerapatan total lamun, maka kandungan muatan padatan tersuspensi di perairan semakin rendah. Bengen (2001) menyatakan bahwa salah satu fungsi ekologis padang lamun sebagai "pengikat" sedimen dan partikel-pertikel bahan organic yang melayang di kolom air di daerah tersebut.

\section{KESIMPULAN}

Hasil pengamatan selama penelitian menunjukkan bahwa kerapatan total vegetasi lamun di suatu perairan dapat mempengaruhi nilai muatan padatan tersuspensi terukur di perairan tersebut. Semakin tinggi nilai kerapatan total lamun, maka akan semakin rendah nilai muatan padatan tersuspensi yang terdapat di perairan tersebut.

\section{UCAPAN TERIMA KASIH}

Penulis menyampaikan ucapan terimakasih kepada para reviewer yang telah mambantu menyempurnakan artikel ini. Ucapan terimakasih juga penulis sampaikan kepada semua pihak yang telah banyak membantu selama pelaksanaan penelitian sehingga penelitian dapat berlangsung dengan lancar.

\section{DAFTAR PUSTAKA}

Alerts , G. \& Santika ,S.S. 1984. Metoda Penelitian air. Penerbit Usaha Nasional, Surabaya.

Bengen, D.G. 2001. Ekosistem dan Sumber Daya Alam Pesisir dan laut .Pusat kajian Sumberdaya Pesisir dan Lautan (PKSPL-IPB) Bogor.

Buckman, H.D. \& N.C. Brady. 1982. The Natural and Properties of Soil. The macmilan Company, New York.

Dawes, C.J. 1981. Marine Botany. A Wiley Interscine Publication, Canada

English, SC, Wilkinson \& V. Baker. 1997. Survey manual for Tropical Marine Resources. Australian Institute of Marine Science. Townsvile 
Fortes, M.D. 1990. Seagrasses: A Resources Unknown in The Asean Region. Iclarm Education Series 5. International Center for Living Aquatic. Resources Management Manila, Philippines.

Hutomo, M. \& M.H. Azkab. 1987. Perairan Lamun di Lingkungan Laut dangkal. Oseana Vol. XII No. 1. LON-LIPI, Jakarta

Kiswara, W. \& Winardi. 1999. Sebaran Lamun di Teluk Kuta dan Teluk Gerupuk, Lombok. Puslitbang $\mathrm{P}_{3} \mathrm{O}-\mathrm{LIPI}$, Jakarta.

Nybaken, J.W. 1988. Biologi Laut, Suatu Pendekatan Ekologis. Gramedia, Jakarta.
Riniatsih, I., \& Widianingsih. 2007. Kelimpahan dan Pola sebaran Kerang-kerangan (Bivalvia) di Ekosistem Padang Lamun Perairan Jepara. Jurnal Ilmu Kelautan. Vol 12 (1) Maret 2007.

Sidjabat, M.M. 1992. Pengantar Oseanografi Bagian Oseanografi IPBBogor.

Triatmodjo, B. 1999. Teknik Pantai. Beta Ofset. Yogyakarta.

Utamingsih, Jaya S, Dermiyaningsih. 1994. Pedoman Analisis Kualitas Air dan Tanah Sedimen Perairan Payau, Balai Budidaya Air Payau. Jepara. 